\section{Physiological Attributes Related to Quality Attributes and Storage Life of Minimally Processed Lettuce}

\author{
R. Couture', M.I. Cantwell, D. $\mathrm{Ke}^{2}$, and M.E. Saltveit, Jr. ${ }^{3}$ \\ Department of Vegetable Crops, Mann Laboratory, University of California, \\ Davis, CA 95616
}

Additional index words. browning, ethylene, Lactuca sativa, cultivar and maturity, phenolics, phenylalanine ammonia-lyase, polyphenol oxidase

\begin{abstract}
Relationships between storage quality attributes, such as russet spotting and browning intensity, and physiological attributes, such as soluble phenolic content and polyphenol oxidase (PPO) and phenylalanine ammonia-lyase (PAL) activities, of minimally processed crisphead lettuce (Lactuca sativa L.) were studied. The processed lettuce tissue was kept in air or air plus ethylene at 2 or $5 \mu \mathrm{l} \cdot \cdot_{\text {liter }}{ }^{-1}$ at 2.5 or $5 \mathrm{C}$ for 1 to 4 days and then transferred to air at $2.5,5$, or $20 \mathrm{C}$ for 1 to several days. None of the above physiological attributes of the initial samples from eight lettuce cultivars (Calmar, EI Toro, Sea Green, Pacific, Monterey, Salinas 88, 86-13, and Nerone) and three maturity stages (immature, mature, and overmature) correlated with their storage quality. However, ethyleneinduced PPO and PAL activities and browning intensity measured 3 to 4 days after harvest consistently and significantly correlated with the final visual quality of the ethylenetreated, minimally processed lettuce after 6 to 10 days of storage. Among these three attributes, ethylene induced a 2.5- to 5.3-fold increase in PAL activity, while the relative changes in PPO activity and browning intensity were only $23 \%$ to $68 \%$. Ethylene-induced PAL activity possibly may be used as an index to predict the storage life of minimally processed lettuce.
\end{abstract}

Recently, minimally processed lettuce has become popular due to its increased use in salad bars and fast food outlets. Chopping or shredding lettuce ruptures cells and initiates wound-induced physiological and biochemical reactions that shorten storage life. Wounding and exposing lettuce to ethylene causes increased respiration, enhanced phenylalanine ammonia-lyase (PAL) activity, accumulation and oxidation of soluble phenolic compounds, cell wall signification, and tissue browning (Hyodo et al., 1978; Ke and Saltveit, 1986, 1988, 1989a). To avoid tissue discoloration and spoilage by microorganisms, modified atmospheres with reduced $\mathrm{O}_{2}$ and elevated $\mathrm{CO}_{2}$ concentrations usually are used during storage and transport- of minimally processed lettuce (Ballantyne et al., 1988; Bolin and Huxsoll, 1991; King et al., 1991; McDonald et al., 1990).

Quality and storage life of minimally processed lettuce vary depending on cultivars, cultural conditions, maturity, processing procedures, and storage conditions such as temperature, $\mathrm{O}_{2}$ and $\mathrm{CO}_{2}$ concentrations, and ethylene concentration (Bolin and Huxsoll, 1991;

Received for publication 4 June 1992. Accepted for publication 16Feb. 1993. The cost of publishing this paper was defrayed in part by the payment of page charges. Under postal regulations, this paper therefore must be hereby marked advertisement solely to indicate this fact.

'Current address: Dept. of Research and Development, A. Lassonde \& Fils, 170 5th Ave., Rougemont, Qué. J0L 1M0, Canada.

${ }^{2}$ Dept. of Pomology.

${ }^{3}$ To whom reprint requests should be addressed.
Bolin et al., 1977; Brecht et al., 1973a, 1973b, 1973c). Large amounts of minimally processed lettuce may spoil during storage and transport because there is no method to predict the product's storage life. The objectives of this research were to study the physiological at- tributes that affect the storage life of minimally processed lettuce and to identify storage quality attributes that may be assessed to predict cut lettuce storage life.

Crisphead lettuce heads were obtained from commercial shippers or growers in Salinas, Calif., and transported to the Mann Laboratory, Univ. of California, Davis. The heads were evaluated immediately after their arrival or after they were stored at $0 \mathrm{C}$ for $<24 \mathrm{~h}$. Wrapper leaves were discarded and the other leaves were tom off and cut perpendicularly to the midrib into $15 \times 30$-mm segments. The minimally processed tissues were rinsed with $\mathrm{NaOCl}$ (chlorine) solution at $100 \mathrm{mg} \cdot \mathrm{liter}^{-1}$ and centrifuged to remove surface water. About $200 \mathrm{~g}$ of tissue was placed in a 2-liter glass jar as one replication and three replications per treatment were used. The jars were covered with four layers of cheesecloth and placed in a 25 -liter metal container at 2.5 or $5 \mathrm{C}$. A continuous flow of air or air plus ethylene at 2 or $5 \mu \mathrm{l} \cdot$ liter $^{-1}$ was passed through the containers at a flow rate sufficient to keep $\mathrm{CO}_{2}$ concentrations $<0.2 \%$. Ethylene concentrations were monitored periodically with a gas chromatography. The tissues were evaluated after 1 to 4 days under the specified conditions or after transfer to air at $2.5,5$, or $20 \mathrm{C}$ for 1 to several days.

Performing a subjective evaluation. Visual quality was estimated based on appearance using a scale of 1 to 9 , where $1=$ very poor and $9=$ excellent. Russet spotting (RS) was scored using a scale of 0 to 9 , where $0=$ no RS and $9=$ severe RS (Ke and Saltveit, 1986).

Determining browning intensity. Ten grams of lettuce tissue was homogenized with $10 \mathrm{ml}$ water. The homogenate was filtered through
Table 1. Visual quality, russet spotting (RS) score, browning intensity, phenolic content, and polyphenol oxidase (PPO) and phenylalanine ammonia-lyase (PAL) activities in minimally processed 'Calmar' lettuce tissues as influenced by exposure to ethylene at $2 \mu \mathrm{l} \cdot$ liter-1 for $1,2,3$, or 4 days at $2.5 \mathrm{C}$ followed by subsequent storage in air for 6 to 10 days at $2.5 \mathrm{C}$.

\begin{tabular}{|c|c|c|c|c|c|c|c|}
\hline \multirow[b]{2}{*}{ Measurement } & \multirow{2}{*}{$\begin{array}{c}\text { Storage } \\
\text { duration } \\
\text { (days) }\end{array}$} & \multicolumn{5}{|c|}{$\begin{array}{l}\text { Ethylene exposure } \\
\text { duration (days) }\end{array}$} & \multirow{2}{*}{$\begin{array}{c}\text { Correlation } \\
\text { coefficient }{ }^{y} \\
(r)\end{array}$} \\
\hline & & 0 & 1 & 2 & 3 & 4 & \\
\hline \multirow[t]{3}{*}{ Visual quality $^{x}$} & $\overline{0}$ & $9 . \overline{0}$ & & & & & \\
\hline & 4 & 8.0 & 7.7 & 7.3 & 7.3 & 7.0 & $0.92^{* *}$ \\
\hline & 10 & 7.0 & 7.0 & 5.7 & 5.0 & 3.3 & \\
\hline RS score ${ }^{w}$ & 10 & 0.0 & 0.7 & 0.7 & 0.7 & 1.7 & $-0.87^{*}$ \\
\hline \multicolumn{8}{|l|}{ Browning intensity } \\
\hline \multirow[t]{3}{*}{$\left(A_{340}\right)$} & 0 & 0.18 & & & & & \\
\hline & 4 & 0.22 & 0.28 & 0.27 & 0.32 & 0.37 & $-0.91^{*}$ \\
\hline & 10 & 0.35 & 0.39 & 0.40 & 0.52 & 0.55 & $-0.92^{* *}$ \\
\hline \multirow{4}{*}{$\begin{array}{l}\text { Phenolic content } \\
\quad\left(\mu \mathrm{g} \cdot \mathrm{g}^{-1}\right)\end{array}$} & & & & & & & \\
\hline & 0 & 169 & & & & & \\
\hline & 4 & 194 & 196 & 170 & 209 & 220 & $-0.59^{\mathrm{Ns}}$ \\
\hline & 10 & 249 & 238 & 237 & 284 & 301 & $-0.87^{*}$ \\
\hline \multirow[t]{2}{*}{$\begin{array}{l}\text { PPO activity } \\
\left(\mu \mathrm{mol} \cdot \mathrm{h}^{-1} \cdot \mathrm{g}^{-1}\right)\end{array}$} & 0 & 1.4 & & & & & \\
\hline & 4 & 1.5 & 1.6 & 1.6 & 2.0 & 2.1 & $-0.91^{*}$ \\
\hline \multirow{2}{*}{$\begin{array}{l}\text { PAL activity } \\
\left(\mu \mathrm{mol} \cdot \mathrm{h}^{-1} \cdot \mathrm{g}^{-1}\right)\end{array}$} & 0 & 0.02 & & & & & \\
\hline & 4 & 0.05 & 0.05 & 0.04 & 0.12 & 0.14 & $-0.87^{*}$ \\
\hline
\end{tabular}

${ }^{2}$ Refers to the total days after harvest, which equals the sum of the days of ethylene exposure and the days of storage after removal from cthylenc.

${ }^{y}$ Correlation between the data in the row and the final visual quality on day 10 . Pooled LSD values at $P=0.05$ were: visual quality, $0.5 ; \mathrm{RS}, 0.2$; browning intensity, 0.05 ; phenolic content, 34 ; PPO activity, 0.3 ; and PAL activity, 0.04 .

${ }^{x}$ Estimated using a scale of 1 (very poor) to 9 (excellent).

"Scored using a scale of 0 (no RS) to 9 (severe RS).

ws,,$* * *$ Nonsignificant or significant at $P \leq 0.05$ or 0.01 , respectively. 
Table 2. Visual quality, browning intensity, phenolic content, and phenylalanine ammonia-lyase (PAL) activity in minimally processed lettuce tissue from eight cultivars measured immediately after harvest (day 0 ) or after exposure to ethylene at $5 \mu \mathrm{l}$-liter ${ }^{-1}$ at $5 \mathrm{C}$ for 3 days (day 3 ) followed by subsequent storage in air at $5 \mathrm{C}$ for 3 days (day 6 ).

\begin{tabular}{|c|c|c|c|c|c|c|c|c|c|c|}
\hline \multirow[b]{2}{*}{ Measurement } & \multirow{2}{*}{$\begin{array}{c}\text { Storage } \\
\text { duration } \\
\text { (days) }\end{array}$} & \multicolumn{8}{|c|}{ Cultivar } & \multirow{2}{*}{$\begin{array}{c}\text { Correlation } \\
\text { coefficient }{ }^{2} \\
(r)\end{array}$} \\
\hline & & Calmar & El Toro & Sea Green & Pacific & Monterey & Salinas 88 & $86-13$ & Nerone & \\
\hline \multirow[t]{3}{*}{ Visual quality ${ }^{y}$} & 0 & 9.0 & 9.0 & 9.0 & 9.0 & 9.0 & 9.0 & 9.0 & 9.0 & $0.00^{\mathrm{NS}}$ \\
\hline & 3 & 9.0 & 9.0 & 9.0 & 9.0 & 9.0 & 9.0 & 8.0 & 9.0 & $0.40^{\mathrm{Ns}}$ \\
\hline & 6 & 7.0 & 7.0 & 7.0 & 5.5 & 4.0 & 4.0 & 3.0 & 2.0 & \\
\hline \multirow{3}{*}{ Browning intensity $\left(A_{340}\right)$} & 0 & 0.32 & 0.27 & 0.28 & 0.35 & 0.32 & 0.29 & 0.31 & 0.42 & $-0.63^{\text {ws }}$ \\
\hline & 3 & 0.30 & 0.24 & 0.19 & 0.26 & 0.29 & 0.29 & 0.26 & 0.40 & $-0.68^{*}$ \\
\hline & 6 & 0.51 & 0.65 & 0.51 & 0.63 & 0.68 & 0.73 & 0.70 & 1.07 & $-0.83^{* *}$ \\
\hline \multirow[t]{2}{*}{ Phenolic content $\left(\mu \mathrm{g} \cdot \mathrm{g}^{-1}\right)$} & 0 & 151 & 137 & 163 & 142 & 145 & 168 & 154 & 211 & $-0.62^{\mathrm{Ns}}$ \\
\hline & 3 & 262 & 228 & 241 & 307 & 293 & 244 & 188 & 368 & $-0.35^{\mathrm{ss}}$ \\
\hline \multirow[t]{2}{*}{ PAL activity $\left(\mu \mathrm{mol} \cdot \mathrm{h}^{-1} \cdot \mathrm{g}^{-1}\right)$} & 0 & 0.04 & 0.03 & 0.03 & 0.04 & 0.05 & 0.04 & 0.04 & 0.04 & $-0.57^{\mathrm{Ns}}$ \\
\hline & 3 & 0.03 & 0.04 & 0.03 & 0.03 & 0.11 & 0.09 & 0.12 & 0.19 & $-0.94^{* *}$ \\
\hline
\end{tabular}

${ }^{z}$ Correlation between the data in the row and the final visual quality on day 6 . Pooled LSD values at $P \leq 0.05$ were: visual quality, $0.6 ;$ browning intensity, 0.06 ; phenolic content, 38; and PAL activity, 0.02 .

ystimated using a scale of 1 (very poor) to 9 (excellent).

${ }^{\mathrm{Ns}, * * *}$ Nonsignificant or significant at $P \leq 0.05$ or 0.01 , respectively.

four layers of cheesecloth and centrifuged at $25,000 \times g$ for $15 \mathrm{~min}$. The supernatant was measured immediately for absorbance at 340 nm with a spectrophotometer to estimate the degree of tissue browning.

Performing phenolic content and enzyme activity assays. Soluble phenolic content and polyphenol oxidase (PPO) and PAL activities were determined as described by Ke and Saltveit (1988) and are expressed in micrograms per gram of fresh weight and micromoles of product formed per hour per gram of fresh weight, respectively.

Evaluating variation with ethylene exposure duration. Exposing lettuce tissue to ethylene induces phenolic metabolism and RS and shortens storage life (Hyodo et al., 1978; Ke and Saltveit, 1986, 1988, 1989a). When minimally processed 'Calmar' lettuce was exposed to ethylene at $2 \mu \mathrm{l} \cdot$ liter $^{-1}$ for only 1 day and then stored in air at $2.5 \mathrm{C}$ for 9 days, final visual quality was similar to that of tissue continuously exposed to air (Table 1). However, exposure to ethylene for 2, 3, or 4 days reduced the product's final visual quality by day 10 . The correlation between ethylene exposure duration and visual quality on day 4 or 10 was highly significant $[r=(-0.97)$ and -0.96 , respectively; $P \leq 0.01]$. Visual quality on day 4 also correlated with final visual quality on day 10. RS was not observed after 4 days of exposure to ethylene at $2.5 \mathrm{C}$, but slight $\mathrm{RS}$ developed by day 10 and correlated significantly with final visual quality.

Generally, longer exposure to ethylene resulted in higher browning intensity, slightly higher soluble phenolic content and PPO activity, and much higher PAL activity (Table 1). Browning intensity on days 4 and 10 correlated significantly with final visual quality on day 10 . Phenolic content on day 10 , but not on day 4 , correlated significantly with final visual quality on day 10. Both PPO and PAL activities on day 4 correlated significantly with final visual quality on day 10 .

The attributes presented in Table 1 are physiologically interrelated. PAL is a key enzyme for phenolic biosynthesis. Background PAL activity in intact lettuce heads is very low. Higher PAL activity can be induced by stress, such as ethylene, $\mathrm{CO}_{2}$, and wounding (Hyodo et al., 1978; Ke and Saltveit, 1986, 1988, 1989a, 1989b). Phenolic content and PPO activity are related to RS development and browning intensity. RS and browning reduce visual quality. Therefore, PAL activity may indicate the degree to which lettuce tissue has been exposed to such stresses. Since the storage life of minimally processed lettuce could be influenced by the stress level occurring during processing, transport, and storage, stress-induced PAL activity may be related to the product's storage life and quality.

Evaluating differences among cultivars. Eight lettuce cultivars (at commercial maturity) with different sensitivities to ethylene were exposed to ethylene at $5 \mu \mathrm{l} \cdot$ liter $^{-1}$ at $5 \mathrm{C}$ for 3 days and evaluated for the attributes that would correlate with their final visual quality after 3 additional days of storage in air at $5 \mathrm{C}$. 'Calmar', 'El Toro', and 'Sea Green' had the highest final visual quality and 'Nerone' had the lowest (Table 2). Visual quality immediately after harvest (day 0 ) and on day 3 did not correlate significantly with final visual quality on day 6 . Browning intensity on day 0 did not correlate significantly with final visual quality. On day 3 , however, it correlated signifi- cantly with final visual quality on day 6. Again, the soluble phenolic content on days 0 and 3 did not correlate significantly with final visual quality on day 6. PAL activity on day 0 did not correlate significantly with final visual quality on day 6 , but PAL activity on day 3 correlated significantly. These results indicated that no tested attributes on day 0 could be used to predict final visual quality on day 6 . However, ethylene-induced PAL activity on day 3 correlated significantly with final visual quality on day 6. Exposure to elevated ethylene levels may induce differences in physiological attributes among lettuce cultivars.

Evaluating variation with maturity stages. 'Cool Guard' lettuce heads were harvested at three maturity stages and the storage quality of their minimally processed tissues was evaluated. Overmature lettuce had the lowest visual quality after 4 days in air at $2.5 \mathrm{C}$ (Table 3 ). An additional day in air at $20 \mathrm{C}$ significantly reduced visual quality at all maturity stages, but immature lettuce had better quality than lettuce from the other two maturity stages. Visual quality of lettuce from all maturity stages on days 0 and 4 did not correlate significantly with final visual quality on day 5 . Browning intensity on days 4 and 5 correlated signifi-

Table 3. Visual quality, browning intensity, and phenolic content of minimally processed 'Cool Guard' lettuce harvested at three maturity stages. The lettuce tissues were evaluated immediately after harvest (day 0 ) or after storage in air at $2.5 \mathrm{C}$ for 4 days (day 4 ) followed by transfer to air at 20C for 1 day (day 5).

\begin{tabular}{|c|c|c|c|c|c|}
\hline \multirow[b]{2}{*}{ Measurement } & \multirow{2}{*}{$\begin{array}{c}\text { Storage } \\
\text { duration } \\
\text { (days) }\end{array}$} & \multicolumn{3}{|c|}{ Maturity stage } & \multirow{2}{*}{$\begin{array}{c}\text { Correlation } \\
\text { coefficient }^{z} \\
(r)\end{array}$} \\
\hline & & Immature & Mature & Overmature & \\
\hline \multirow[t]{3}{*}{ Visual quality ${ }^{y}$} & 0 & 9.0 & 9.0 & 9.0 & $0.00^{\mathrm{Ns}}$ \\
\hline & 4 & 7.0 & 7.0 & 5.6 & $0.50^{\mathrm{ws}}$ \\
\hline & 5 & 5.5 & 2.5 & 2.5 & \\
\hline \multicolumn{6}{|c|}{ Browning intensity } \\
\hline \multirow{3}{*}{$\left(A_{340}\right)$} & 0 & 0.14 & 0.15 & 0.13 & $0.00^{\text {ws }}$ \\
\hline & 4 & 0.30 & 0.34 & 0.37 & $-0.90^{*}$ \\
\hline & 5 & 0.49 & 0.64 & 0.66 & $-0.94^{*}$ \\
\hline \multicolumn{6}{|l|}{ Phenolic content } \\
\hline \multirow[t]{3}{*}{$\left(\mu \mathrm{g} \cdot \mathrm{g}^{-1}\right)$} & 0 & 133 & 134 & 114 & $0.46^{\mathrm{Ns}}$ \\
\hline & 4 & 161 & 178 & 186 & $-0.95^{*}$ \\
\hline & 5 & 232 & 214 & 236 & $0.34^{\mathrm{Ns}}$ \\
\hline
\end{tabular}

${ }^{2}$ Correlation between the data in the row and the final visual quality on day 5. Pooled LSD values at $P \leq 0.05$ were: visual quality, 0.5 ; browning intensity, 0.06 ; and phenolic content, 27.

${ }^{y}$ Estimated using a scale of 1 (very poor) to 9 (excellent).

${ }_{N s,}{ }^{*}$ Nonsignificant or significant at $P \leq 0.05$, respectively. 
cantly with final visual quality on day 5 , although browning intensity on day 0 did not correlate significantly. Soluble phenolic content on days 0 and 5 did not correlate significantly with final quality on day 6 , but phenolic content on day 4 correlated significantly.

We conclude that no tested attributes on day 0 could be used to predict storage life and final quality of minimally processed lettuce. RS score, phenolic content, and visual quality from earlier measurements did not consistently correlate significantly with final quality and, therefore, cannot be used to predict storage life. However, after the processed lettuce was exposed to an elevated ethylene concentration for a few days, browning intensity and PPO and PAL activities correlated significantly with final storage quality of various lettuce cultivars and ethylene exposure durations. Among these three attributes, the magnitude of changes in browning intensity and PPO activity on day 3 or 4 was small (23\% to $68 \%$ ), a magnitude that would not help predict final quality. However, ethylene-induced PAL activity on day 3 or 4 consistently correlated significantly with final storage quality of ethylene-treated, minimally processed lettuce; the magnitude of changes in PAL activity was $250 \%$ to $530 \%$. Thus, ethylene-induced PAL activity possibly may be used as an index to predict storage life and quality of minimally processed lettuce.

\section{Literature Cited}

Ballantyne, A., R. Stark, and J.D. Selman. 1988 Modified atmosphere packaging of shredded lettuce. Intl. J. Food Sci. Tech. 23:267-274.

Bolin, H.R. and C.C. Huxsoll. 1991. Effect of preparation procedures and storage parameters on quality retention of salad-cut lettuce. J. Food Sci. 56:60-67.

Bolin, H.R., A.D. Stafford, J.R. King, and C.C. Huxsoll. 1977. Factors affecting the storage stability of shredded lettuce. J. Food Sci. 42:1319-1321.

Brecht, P.E., A.A. Kader, and L.L. Morns. 1973a Influence of the postharvest temperature on brown stain of lettuce. J. Amer. Soc. Hort. Sci. 98:399-402.

Brecht, P.E., A.A. Kader, and L.L. Morris. 1973b. The effect of composition of the atmosphere and duration of exposure on brown stain of lettuce. J. Amer. Soc. Hort. Sci. 98:536-538.

Brecht, P.E., L.L. Morns, C. Cheyney, and D. Janecke. 1973c. Brown stain susceptibility of selected lettuce cultivars under controlled atmo- spheres and temperatures. J. Amer. Soc. Hort. Sci. 98:261-264.

Hyodo, H., H. Kuroda, and S.F. Yang. 1978. Induction of phenylalanine ammonia-lyase and increase in phenolics in lettuce leaves in relation to the development of russet spotting caused by ethylene. Plant Physiol. 62:31-35.

Ke, D. and M.E. Saltveit, Jr. 1986. Effects of calcium and auxin on russet spotting and phenylalanine ammonia-lyase activity in iceberg lettuce. HortScience 21:1169-1 171.

Ke, D. and M.E. Saltveit, Jr. 1988. Plant hormone interaction and phenolic metabolism in the regulation of russet spotting in iceberg lettuce. Plant Physiol. 88:1136-1140.

Ke, D. and M.E. Saltveit, Jr. 1989a. Wound-induced ethylene production, phenolic metabolism and susceptibility to russet spotting in iceberg lettuce. Physiol. Plant. 76:412-418.

Ke, D. and M.E. Saltveit, Jr. 1989b. Carbon dioxide induced brown stain development as related to phenolic metabolism in iceberg lettuce. J. Amer. Soc. Hort. Sci. 114:789-794.

King, A.D., Jr., J.A. Magnuson, T. Torok, and N. Goodman. 1991. Microbial flora and storage quality of partially processed lettuce. J. Food Sci. 56:459-461.

McDonald, R.E., L.A. Risse, and C.R. Barmore. 1990. Bagging chopped lettuce in selected permeability films. HortScience 25:671-673. 